Поступила в редакцию: 20.05.2020

Принята к публикации: 01.06 .2020

Опубликована онлайн: 30.06 .2020

ISSN 1609-0691

\title{
Литологическая школа Воронежского госуниверситета
}

\author{
(C2020 Д. А. Иванов ${ }^{\text {冈 }}$ \\ ${ }^{1}$ Воронежский государственный университет, \\ Университетская пл., 1, 394018, Воронеж, Российская Федерация
}

\begin{abstract}
Аннотация
В статье рассмотрено становление литологической школы ученых в рамках геологического факультета Воронежского госуниверситета. Перечислены профессора, стоящие у истоков основания геологического факультета ВГУ и литологического направления исследований. Прослежено формирование во времени различных направлений литологических исследований докембрия и фанерозоя как по индивидуальным научным школам, так и по направлениям, связанным с различными видами минерального сырья. Приведены данные о докторах и кандидатах наук литологической школы ВГУ. Показан результат практической деятельности ученых-литологов ВГУ на примере работ по составлению комплектов государственных геологических карт масштаба 1:200000.

Ключевые слова: ВГУ, научная школа, литология

Для циитирования: Иванов Д. А. Литологическая школа Воронежского госуниверситета // Вестник Воронежского государственного университета. Серия: Геология. 2020. №2. С. 98-103. DOI: https://doi.org/10.17308/geology.2020.2/2865
\end{abstract}

Воронежский университет был образован указом В. И. Јенина в 1918 г. и связан с переводом Юрьевского (Тартуского) университета в Воронеж. В университете среди других учебных подразделений имелась кафедра геологин, на основе которой в 1934 г. был организован геологический факультет. В его составе преподавали видные ученые в области осадочной геологии, основавшие литологическую школу ВГУ. С тех пор по настоящее время в её деятельности принимали участие шесть поколений ученых-литологов (рис. 1). Они внесли большой вклад в исследования и открытие месторождений различных видов минерального сырья в бывшем СССР, а также ряде зарубежных стран. Но основные работы проводились в пределах Воронежской антеклизы.

У истоков воронежской школы литологии в конце тридцатых годов стояли первый декан факультета А. А. Дубянский и последующие - Е. К. Лазаренко, Г. П. Горшков, а также заведующий кафедрой исторической геологии Д. И. Дамперов. Но масштабные работы в области осадочной геологии начали осуществляться с приходом на факультет фронтовиков. В это время были заложены два основных направления литология осадочных и осадочно-метаморфических пород. Первое возглавил крупный ученый проф. С. Г. Вишняков, приглашенный из Ленинграда, второе Н. А. Плаксенко, известный специалист в области изучения железистых кварцитов. Одновременно с ними вели исследования и готовили учеников М. Н. Гришенко в области литологии четвертичных отложений, Н. П. Хожаинов, изучавший терригенные отложения и В.П. Семенов, который занимался палеогеновыми образованиями.

Вопросами литологии осадочно-метаморфических пород КМА занимался Н. А. Плаксенко, на Кольском полуострове - академик А. В. Сидоренко и проф. М.С. Точилин, работавшие до войны по окончанию учебы ассистентами на геологическом факультете. Они являлись учениками основателей факультета. А. В. Сидоренко является основателем осадочной геологии докембрия, М. С. Точилин зашитил докторскую диссертацию по липецким железным рудам, а затем изучал джеспилиты КМА и Балтийского щита. Этот ученый совмещал работу в Кольском филиале $\mathrm{AH} \mathrm{CCCP}$ с преподаванием в Воронежском университете.

Расцвет исследований в области литологии приходится на 60-80 гг. прошлого столетия. Это время

Контент доступен под лицензией Creative Commons Attribution 4.0 License.

\footnotetext{
๑ Иванов Дмитрий Андреевич, e-mail: ivanov@geol.vsu.ru
} 
обширных геологоразведочных работ и их научного сопровождения. Проводилось опорное бурение, открывались месторождения месторождения железных руд и бокситов на КМА, медно-никелевых руд в Воронежской, титан-циркониевых россыпей в Тамбовской, месторождения карбонатных пород в Липецкой области. Полученные данные по месторождениям изучались, обобщались и использовались в прогнозных построениях.

В это время вышли из печати крупные работы «Геология, гидрогеология и железные руды КМА, (1969)» коллектива авторов, «Главнейшие закономерности железорудного накопления в докембрии, 1966» Н. А. Плаксенко, «Палеоген Воронежской антеклизы, 1965» В. П. Семенова, «Глинистые породы верхнего протерозоя и фанерозоя Воронежской антеклизы, 1988» А. Д. Савко и ряд других монографий. Публикуются тематические сборники, многочисленные статьи в местных, центральных и зарубежных изданиях, защищаются кандидатские и докторские диссертации по литологии.

В годы перестройки резко упал объём геологоразведочных работ, а, следовательно, и поступление каменного материала. Но Министерство природных ресурсов, для поддержки учебного процесса и подготовки геологов-съёмщиков, в 1992 г. приняло решение вести геолого-съёмочные работы ГДП-200 в регионе силами литологов ВГУ. Будучи заместителем министра геологии СССР, Виктор Петрович Орлов неоднократно был председателем ГЭК при защите дипломных работ студентами геологического факультета ВГУ. К студентам и выпускникам нашего факультета он относился с вниманием и теплотой. Заведующий кафедрой исторической геологии и палеонтологии Савко А.Д. долго проповедовал мысль о том, что в Америке и некоторых других странах геолого-съемочными работами занимаются факультеты университетов. Зная высокий уровень подготовки воронежских геологов - студентов и специалистов, В. П. Орлов предложил А. Д. Савко (зав. кафедрой исторической геологии и палеонтологии) в конце 1991 г. создать группу сотрудников, которая будет вести геологосъемочные работы. В этих работах предполагалось широкое участие преподавателей и студентов факультета. В процессе работ они получали бы новый фактический и аналитический материал для написания дипломных, курсовых работ и диссертаций.

В 1992 г. был написан проект, и начались работы по ГДП-200, гидрогеологической и инженерно-геологической съемке с геоэкологическими исследованиями в пределах листа M-37-XVI (Россошь). Позднее к этой территории с юга была добавлена часть листа М-37-XXII (Кантемировка) (территория РФ). В первые годы ответственным исполнителем работ был А. И. Трегуб доцент кафедры общей геологии. Но в связи с большой загруженностью педагогической работой он не смог выполнять обязанности ответственного исполнителя, и в 1992 г. они были переложены на Глушкова Б. В. Он был ответственным исполнителем при проведении этих работ с 1992 по 2006 г. Позднее ответственным исполнителем работ по ГДП-200 назначен выпускник геологического факультета ВГУ А. В. Черешинский. С 1992 г. и по настоящее время работами бессменно руководит заведующий кафедрой исторической геологии и палеон- тологии, профессор А. Д. Савко.

Работы проводятся на территории ЦентральноЧерноземного региона коллективом сотрудников НИИ геологии и геологического факультета с привлечением студентов-старшекурсников. В состав работ входит: проведение геологических маршрутов, проходка горных выработок, бурение картировочных скважин, описание и карьеров, опробование обнажений и керна скважин. В процессе работ студенты получают практические навыки проведения геологических работ и материалы для написания курсовых, дипломных и магистерских работ и диссертаций.

С 1992 года и по настоящее время проведены работы по ГДП-200 и подготовлены к изданию следующие листы (рис. 2):

1992-1999 гг. - листы М-37-XVI (Россошь) и М-37XXII (Кантемировка);

1999-2003 гг. - листы N-37-ХХХ (Тамбов) и N-37XXXVI (Рассказово);

2003-2006 гг. - листы N-37-XXIX (Мичуринск) и М37-I (Курск);

2006-2009 гг. - лист N-37-XXXI (Малоархангельск);

2009-2012 гг. - лист М-37-II (Кшенский);

2011-2014 гг. - лист М-37-III (Касторное);

2014-2017 гг. - лист N-37-XXXIII (Елец);

2016-2019 гг. - лист М-37-XI (Бобров).

В ходе перечисленных работ было сделано много нового для понимания геологического строения, стратиграфии и состава толщ осадочного чехла. Все материалы, подготовленные по этим листам, относятся к авторским комплектам государственных геологических карт второго поколения, впервые выполненным в цифровом электронном виде с базами первичных и сопровождающих данных. Выявлены десятки прогнозных площадей и перспективных участков на целый ряд полезных ископаемых: титан-циркониевых россыпей, тугоплавких, керамических и бентонитовых глин, фосфоритов, цеолитов, карбонатного сырья, урана, опираясь на материалы предшествующих работ и уточненные геологические данные, в породах кристаллического фундамента выделены прогнозно-минерагенические площади на золото, медь, никель, кобальт. На прогнозных площадях обнаружены многие проявления осадочных полезных ископаемых, разведаны месторождения бентонитовых глин, цеолит-кремнистого сырья, вторичных каолинов (рис. 3).

Научные работы были сосредоточены на изучении преимущественно неметаллического сырья. Исследовались огнеупорные и тугоплавкие глины, бентониты, фосфориты, кремнистое и карбонатное сырьё. Открыта цеолитоносная провинция в кайнозойских отложениях. Полученные научные результаты легли в основу нескольких монографий: «Коры выветривания в геологической истории Восточно-Европейской платформы, 1991», «Фосфориты ЦЧР, 1994», «Титанциркониевые россыпи ЦЧР, 1995» и другие.

В начале XXI столетия литологические исследования продолжались. Их особенностью было широкое внедрение компьютерных технологий и прецизионных методов исследований. Это сказалось на резком усилении работ по осадочно-метаморфическим комплексам раннего докембрия. Полученные радиологические датировки возрастов и данные изотопной 


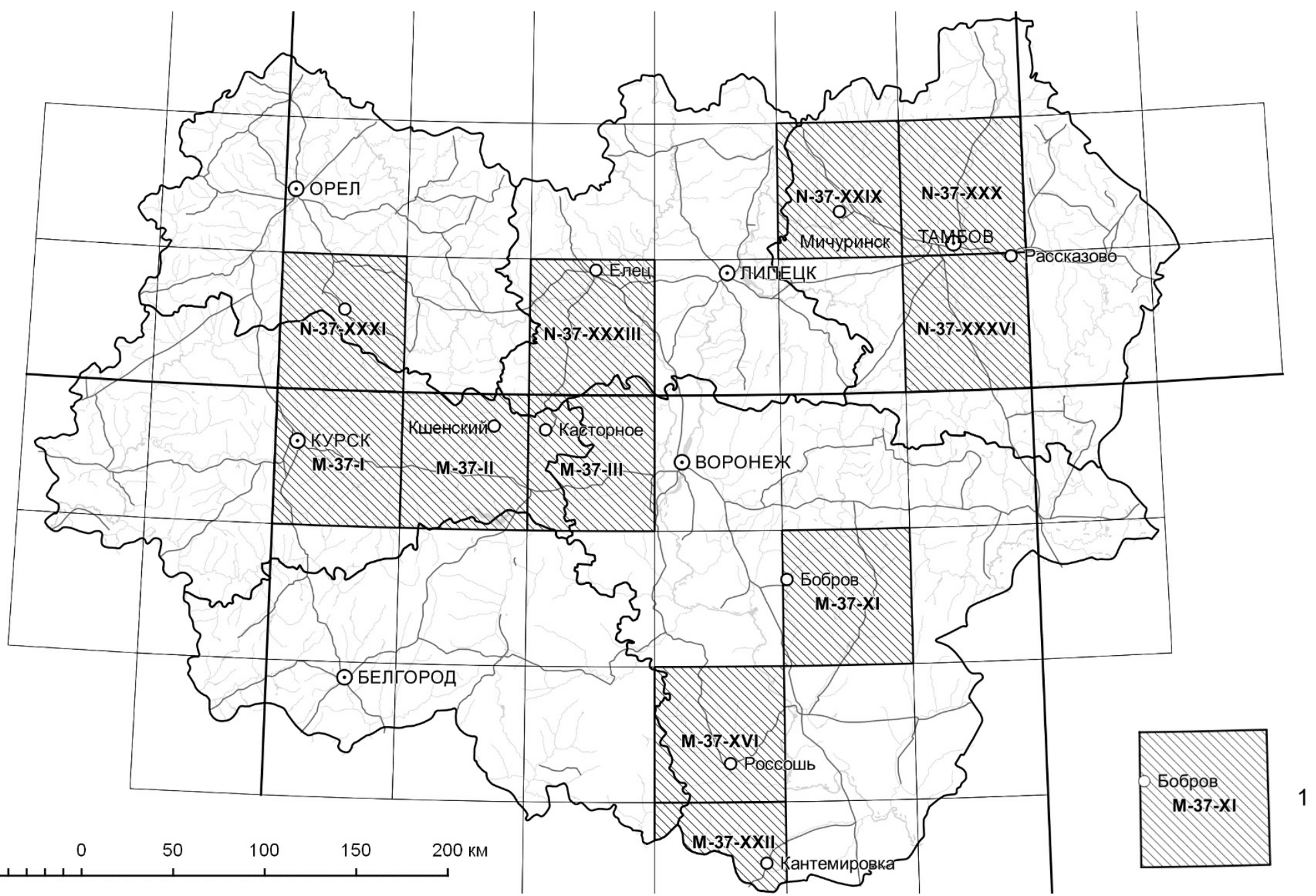

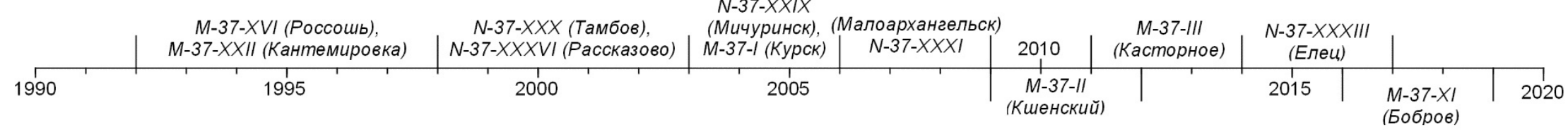



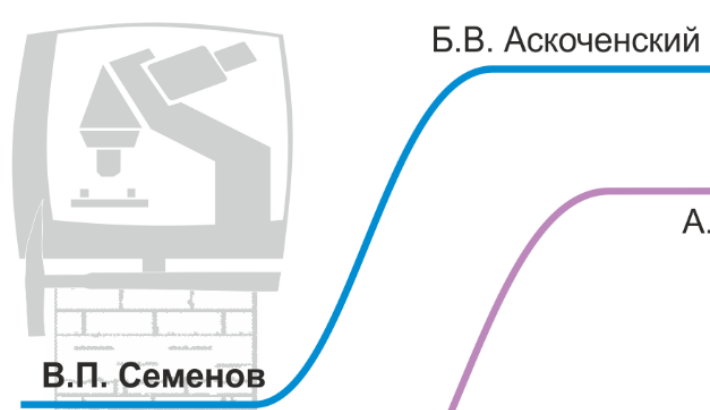

В.Н. Селезнев

П.В. Семенов

Силицить

В.М. Ненахов

С.В. Бондаренко

А.А. Жуковский

Г.С. Золотарева

Титан-циркониевые россыпи А.В. Милаш

В.К. Бартенев А.Е. Звонарев

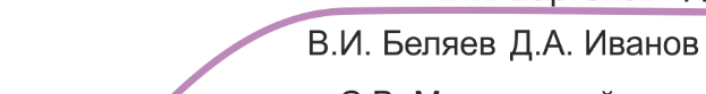

С.В. Мануковский

Абдель Мугхни М.В.

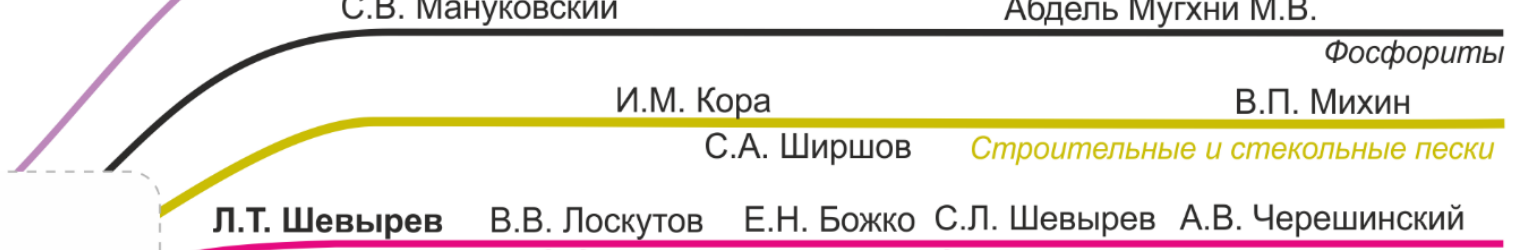
Эндогенные процессы в осадочном чехле Ультратонкое золото Д.А. Дмитриев А.Г. Чигарев В.А. Свиридов Н.П. Хожаинов

В.И. Беляев А.Д. Савко Цеолит-кремнистые породы

\section{В.Н. Бурыкин В.А. Окороков Е.О. Иванова}

В.Н. Бурыкин В.А. Окороков Е.О. Иванова
Карбонатные породы (известняки, доломиты, мергели, писчие мела)
В.Н. Староверов
В.А. Андреенков

А.И. Мизин В.В. Горюшкин Керамические глины, каолины, бентониты

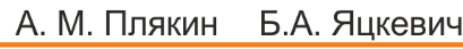

\section{С.Г. Вишняков}

В.И. Сиротин

Г.В. Войцеховский

\section{В.А. Шатров}

Бокситы Тихвина

В.И. Сиротин Б.Н. Одокий

В.А. Шатров

Е.Е. Белявцева

Бокситы КМА

И.И. Никулин

А.И. Дубянский

с.И. Чайкин

П.М. Горяинов

Богатые железные руды член-кор. РАН

К.А. Савко

Железные руды

\section{М.С. Точилин}

И.Н. Щеголев В.А. Канцеров

В.М. Холин

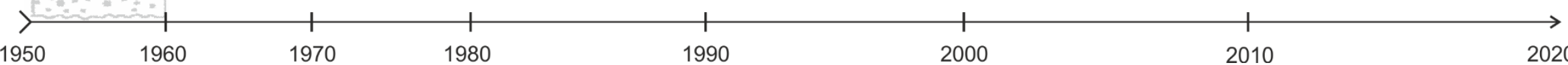

1970

1980

1990

2000

2010

2020

[Fig. 3. Study of eluvial, sedimentary and metamorphogenic-sedimentary mineral raw materials by scientists of the lithological school of VSU.] 
И элементной геохимии позволили определять условия и геодинамические обстановки формирования осадочных бассейнов архея и протерозоя.

Тематика изучения толщ фанерозоя пополнилась работами по золото- и алмазоносности региона. Составленный Атлас фациальных карт (2004г.) (54 стратиграфических подразделения) явился основой для прогнозных построений при поисках осадочных полезных ископаемых. За время деятельности литологической школы ВГУ опубликованы десятки научных монографий и сотни статей в различных изданиях. Некоторые из них, отражающие лицо школы, приведены в таблице. Результаты проведенных работ использовались в учебном процессе при создании методических пособий «Геология Воронежской антеклизы, 2002», «Историческая минерагения, 2005, 2007, 2008», «Эволюция геологических процессов в истории Земли, 2008», «Минерагения кор выветривания, 2016» и др.

За время работы учеными литологической шшколы Воронежского государственного университета было защищено более 50-ти кандидатских диссертаций и более 20-ти докторских (рис. 1).

На современном этапе литологические исследования продолжаются. Они помимо научной имеют практическую направленность. Это позволяет литологической школе Воронежского университета в современных условиях сохранить и сочетать исследовательскую деятельность с учебным процессом.

Конфликт интересов: авторы декларируют отсутствие явных и потенциальных конфликтов интересов, связанных с публикацией настоящей статьи.

\title{
CURRENT EVENTS
}

DOI: https://doi.org/10.17308/geology.2020.2/2865

Received: 20.05 .2020

Accepted: 01.06.2020

Published online: 30.06 .2020

\section{Lithological school of Voronezh State University}

\author{
(C) 2020 D. A. Ivanov ${ }^{\bowtie}$ \\ ${ }^{1}$ Voronezh State University, 1 Universitetskaya pl., 394018 Voronezh, Russian Federation
}

\begin{abstract}
The article is considers the formation of a lithological school of scientists within the geological faculty of Voronezh State University. The professors who are at the origins of the foundation of the geological faculty of VSU and the lithological direction of research are listed. The formation of various directions of lithological research of Precambrian and Phanerozoic both in individual scientific schools and in areas related to various types of mineral raw materials has been traced. Data on PhD и Dr.habil in Geol.-Min. of the lithological school of VSU are given. The result of the practical work of VSU lithologist is shown on the example of work on the compilation of sets of State geological maps on a scale of 1:200,000.

Key words: VSU, scientific school, lithology.

For citation: Savko A. D., Ivanov D. A. Lithological school of Voronezh State University. Vestnik Voronezhskogo gosudarstvennogo universiteta. Seriya: Geologiya = Proceedings of Voronezh State University. Series: Geology, 2020, no. 2, pp. 98-103. DOI: https://doi.org/10.17308/geology.2020.2/2865 Conflict of interests: The authors declare the absence of obvious and potential conflicts of interest related to the publication of this article.
\end{abstract}

Иванов Дмитрий Андреевич - к. г.-м. н., доцент ВГУ, Воронеж, РФ; E-mail: ivanov@geol.vsu.ru ORCID https://orcid.org/0000-0002-2484-393X

Автор прочитал и одобрил окончательный вариант рукописи.
Dmitry A. Ivanov - PhD in Geol-Min., Associate Professor, VSU, Voronezh, RF; E-mail: ivanov@ geol.vsu.ru ORCID https://orcid.org/0000-0002-2484-393X

Author have read and approved the final manuscript.

The content is available under Creative Commons Attribution 4.0 License.

\footnotetext{
Dmitry A. Ivanov, e-mail: ivanov@geol.vsu.ru
} 